Abstracta Iranicacta Iranica

Revue bibliographique pour le domaine irano-aryen

Volume 28 | 2007

Comptes rendus des publications de 2005

\title{
"A new date for the death of Giorgi Saak'adze ». Eurasian Studies, IV/1, 2005, pp. 19-27.
}

\section{Maria Szuppe}

\section{(2) OpenEdition}

1 Journals

\section{Édition électronique}

URL : http://journals.openedition.org/abstractairanica/18031

DOI : 10.4000/abstractairanica.18031

ISSN : 1961-960X

Éditeur :

CNRS (UMR 7528 Mondes iraniens et indiens), Éditions de l'IFRI

\section{Édition imprimée}

Date de publication : 15 mai 2007

ISSN : 0240-8910

\section{Référence électronique}

Maria Szuppe, « «A new date for the death of Giorgi Saak'adze ». Eurasian Studies, IV/1, 2005, pp. 19-27. », Abstracta Iranica [En ligne], Volume 28 | 2007, document 194, mis en ligne le 18 septembre 2007, consulté le 25 septembre 2020. URL : http://journals.openedition.org/abstractairanica/18031 ; DOI : https://doi.org/10.4000/abstractairanica.18031

Ce document a été généré automatiquement le 25 septembre 2020.

Tous droits réservés 
"A new date for the death of Giorgi Saak'adze ». Eurasian Studies, IV/1, 2005, pp. 19-27.

Maria Szuppe 
1 La recherche sur les relations entre la Géorgie et les Safavides s'est beaucoup enrichie ces dernières années, depuis que l'accès aux archives nationales et aux bibliothèques de Géorgie est devenu plus aisé. Le présent article s'intéresse à la carrière militaire d'un personnage important de l'histoire géorgienne du XVII ${ }^{e}$ s., Giorgi Saak'adze (exécuté en 1629). Comme de nombreux nobles et militaires géorgiens, il chercha à faire carrière auprès d'un des deux États rivaux dans la région: la Turquie ottomane et l'Iran safavide. La singularité du parcours de Saak'adze réside dans le fait qu'il avait été successivement au service des Safavides, puis des Ottomans (par qui il avait été nommé beylerbey de Karaman); en conséquence, il s'était converti à l'Islam à deux reprises, une fois en tant que chiite, et une autre fois en tant que sunnite.

2 G. Rota réexamine les données concernant la mort de ce personnage éminent de son époque, en y ajoutant plusieurs nouveaux documents provenant des sources vénitiennes (conservés aux Archives nationales de Venise). La lecture contradictoire des documents vénitiens, contemporains de sa mort, et des sources ottomanes, déjà connues auparavant, mène l'A. à la conclusion qu'il est nécessaire de revoir les circonstances et la date de l'exécution de Giorgi Saak'adze. Il semblerait en effet non seulement que son exécution eut lieu le 29 septembre 1629 (et non pas le 3 octobre de la même année, comme l'affirme Katib Çelebi, suivi par les chroniqueurs plus tardifs), mais qu'au moment de sa chute, Giorgi Saak'adze était engagé dans les négociations secrètes avec la cour safavide pour repasser à son service. Pour ces négociations, Saak'adze aurait activé ses anciens contacts géorgiens chez les Safavides, avec qui il était apparemment resté en bons termes, notamment Rostam Hुān, ġolām haut placé à la cour, dont le vrai nom était Hुosrow Mīrzā Bagrat'ioni, mais aussi un frère d'Emām-Qolī Hูān, le puissant gouverneur du Fārs.

\section{INDEX}

Thèmes : 4.2.1. Safavides et Qâjârs

\section{AUTEURS}

MARIA SZUPPE

CNRS / Mondes iranien et indien - Paris 